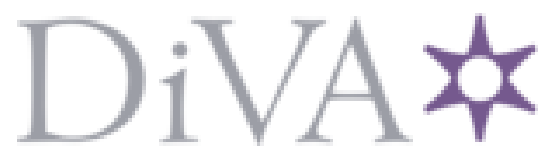

http://www.diva-portal.org

This is the published version of a paper presented at EUROCALL 2015, Padova, Italy.

Citation for the original published paper:

Allen, C. (2015)

Social media as an alternative to Moodle in EFL teaching practice forums.

In: Francesca Helm, Linda Bradley, Marta Guarda, Sylvie Thouësny. (ed.), Critical CALL

- Proceedings of the 2015 EUROCALL Conference, Padova, Italy (pp. 9-15). Researchpublishing.net

http://dx.doi.org/10.14705/rpnet.2015.000303

N.B. When citing this work, cite the original published paper.

Permanent link to this version:

http://urn.kb.se/resolve?urn=urn:nbn:se:Inu:diva-48624 


\title{
Social media as an alternative to Moodle in EFL teaching practice forums
}

\author{
Christopher Allen ${ }^{1}$
}

\begin{abstract}
This paper reports on the preferences among a group of pre-service English as a Foreign Language (EFL) teacher trainees for social media rather than Moodle, an institutional Virtual Learning Environment (VLE), as a forum for support during a recent five week teaching practice in southern Sweden. The teacher trainees responded to a questionnaire relating to preferences for their own Facebook group as opposed to the Moodle forum set up specifically by the course tutor for the purpose of sharing observations and discussing lesson planning, aspects of reflective practice and resources while on teaching practice. Their reflections shed interesting light on the importance of student EFL teacher ownership and 'student centricity' in the learning space. These concepts emerge from a consideration of the learning space at the intersection of pedagogical, technological and content knowledge and the nature of forum discussions when faced with the alternative between social media and institutionalized learning platforms under the direction of teacher trainers and course managers.
\end{abstract}

Keywords: teaching practice, online forums, VLE, social media.

\section{Introduction}

\subsection{General}

In recent years, VLEs or Learning Management Systems (LMSs) such as Moodle, It's Learning and Blackboard have become ubiquitous in higher education. However it is not always the case that institutionally-administered learning platforms can satisfy both the pedagogical and administrative demands of students especially in the collaborative era entailed by Web 2.0 (Weller, 2007a). This point is especially

1. Linnaeus University, Kalmar, Sweden; christopher.allen@Inu.se

How to cite this article: Allen, C. (2015). Social media as an alternative to Moodle in EFL teaching practice forums. In F. Helm, L. Bradley, M. Guarda, \& S. Thouësny (Eds), Critical CALL - Proceedings of the 2015 EUROCALL Conference, Padova, Italy (pp. 9-15). Dublin: Research-publishing.net. http://dx.doi.org/10.14705/rpnet.2015.000303 
pertinent with regards to vocationally-orientated degree programmes involving periods of professional practice away from the campus environment of the training institution.

A period of teaching practice or practicum is an integral part of EFL teaching training courses all over the world, forming an essential component of international courses in teacher certification such as the CELTA, DELTA and TKT administered by Cambridge ESOL as well as programmes leading to qualified teacher status in the state systems of many countries. This paper looks at the role of social media and VLEs such as Moodle in providing support and fostering a sense of community among pre-service teacher trainees.

\subsection{VLEs in higher education}

Despite their widespread popularity in universities and schools, VLEs have been criticized as being mere embodiments of a traditional, institutionalized pedagogy based on a teacher-centred classroom model (Weller, 2006, 2007b). More recently in the light of social media however, critical voices have been raised about VLEs as purveyors of static, unimaginative content, leaving students to go elsewhere to do their learning (Weller, 2006, 2007a). Another important criticism is that behind the institutionalized walls of the VLE, students cannot easily share learning experiences with outsiders.

The use of VLEs has not of course been restricted to purely academic degree programmes and modules. Vocationally-orientated programmes such as teacher training and nursing have also made increasing use of VLEs such as Moodle to provide pre-course tasks, course materials and assignments, videos and information about post-course job opportunities. It is suggested here that VLEs can play an important part in the development of a form of transient 'community of practice' in Lave and Wenger's (1991) terms or learning space while students are away from the host institution engaged in professional training.

\subsection{Moodle forums}

Although the current generation of VLEs typically incorporate a variety of tools and functions for teacher-student and student-student communication, the main function in focus in this article is the forum function. VLE forums provide the opportunity for students to participate in online discussions under the direction of the tutors, to initiate discussions themselves or alternatively to respond to postings from their fellow student teachers. 


\subsection{Facebook and other social media forums}

While many university and teacher training college programmes increasingly rely on institutional VLE forums for the delivery of course content, student teachers are perhaps more likely to regularly access the online forums of social media such as Facebook and other virtual communities outside of their formal education. With the massive impact of smartphone and $4 \mathrm{G}$ technology permitting 'on the fly' postings via social media apps, this trend in the digital behaviour of many young people has become increasingly well-established.

\section{Method}

The ten student teachers (seven women, three men) who responded to the questionnaire in this study were aged between 20 and 27 and in their fourth term of studying English language didactics. An integral part of the teacher training programme in English is the use of Moodle as a VLE (Figure 1).

Figure 1. Screenshot from the Moodle forum set up for the student group for their teaching practice period (in Swedish, verksamhetsförlagd utbildning or $V F U$ )

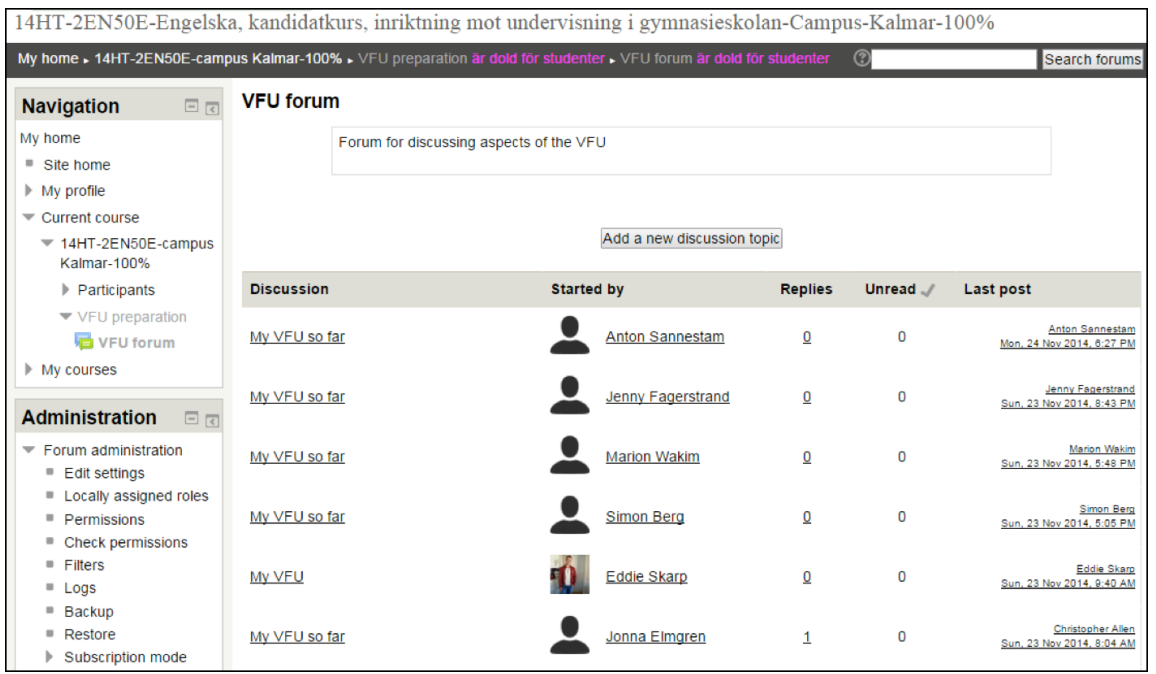

The questionnaire was distributed via the Moodle platform and was made up of three parts. Part A (3 questions) asked about general ICT skills among the teachers and use of social media and VLEs in their previous studies at upper secondary 
school level. Part B (8 questions) focused more specifically on the importance of internet forums within the teaching practice, while finally Part $C$ ( 8 questions) invited a more detailed comparison between social media (e.g. Facebook) and Moodle as a forum for reflection and support during the five weeks of teaching practice.

\section{Results}

\subsection{Part A: previous experience of social media and VLEs in educational contexts}

All of the respondents rated their knowledge of ICT skills and resources relatively highly, with an average score of 6.7 on the scale of 1 (beginner) and 10 (expert). In Prensky's (2001) terms, respondents were all digital natives, making extensive use of social media with extensive personal learning environments both in private and as part of their studies.

\subsection{Part B: online forums for teaching practice support}

The results from Part $B$ of the survey confirmed the general picture of the importance given to online forums among teacher trainees. These results are summarized in Table 1 below. Ratings of importance were given on the scale of 7 (very important) to 1 (not important); the circle $\cdot$ indicated a mean scoring for each of the forum usage areas. Thus for question (1), the use of forums for exchanging lesson plan tips, the average score among the respondents was 5.9 out of 7 . The results indicated the greatest importance attached to exchanging teaching resource tips as well as posing questions to the tutor about language (grammar, lexis, phonology etc) or use of literature in the classroom. Interestingly, forums were seen as less important for reflecting on lesson planning goals and achievement and classroom management.

\subsection{Part C: comparison between social media and Moodle for teaching practice support}

In the final part of the questionnaire, student teachers were asked to compare social media and Moodle as a VLE in terms of the usage areas outlined above. The results across these areas of usage confirmed the preference (with one significant exception) for forums within social media such as Facebook or Edmodo rather than the institutional Moodle. These results are shown below in Figure 2. The one significant departure from this overall finding was question 7 , the use of the forum for the discussion of administrative problems during the teaching practice period. 
Table 1. Average ratings for the importance of usage domains in online forums among student teachers on teaching practice

\begin{tabular}{|c|c|c|c|c|c|c|}
\hline \multicolumn{7}{|c|}{ Very important } \\
\hline 7 & 6 & 5 & 4 & 3 & 2 & 1 \\
\hline \multicolumn{7}{|c|}{0} \\
\hline \multicolumn{7}{|c|}{ 2. Reflecting on achievement of lesson planning goals } \\
\hline \multicolumn{7}{|c|}{ Very important $\quad$ not important } \\
\hline 7 & 6 & 5 & 4 & 3 & 2 & 1 \\
\hline \multicolumn{7}{|c|}{$\begin{array}{c}0 \\
0\end{array}$} \\
\hline \multicolumn{7}{|c|}{ 3. Reflecting on teacher role } \\
\hline \multirow{2}{*}{\multicolumn{3}{|c|}{$\begin{array}{ll}\text { Very important } \\
\end{array}$}} & \multicolumn{4}{|c|}{ not important } \\
\hline & & & 4 & 3 & 2 & 1 \\
\hline \multirow{2}{*}{\multicolumn{7}{|c|}{$\frac{0}{4 \text { Reflecting on clascronm management }}$}} \\
\hline \multirow{2}{*}{\multicolumn{7}{|c|}{$\begin{array}{l}\text { 4.Reflecting on classroom management } \\
\text { Very important } \\
\text { not important }\end{array}$}} \\
\hline & & & & & & \\
\hline 7 & 6 & 5 & 4 & 3 & 2 & 1 \\
\hline \multicolumn{7}{|c|}{0} \\
\hline \multirow{2}{*}{\multicolumn{7}{|c|}{$\begin{array}{l}\text { 5. Exchanging resource tips } \\
\text { Very important }\end{array}$}} \\
\hline & & & & & & \\
\hline 7 & 6 & 5 & 4 & 3 & 2 & 1 \\
\hline \multicolumn{7}{|c|}{0} \\
\hline \multirow{2}{*}{\multicolumn{7}{|c|}{ 6. Asking questions about language / literary analysis }} \\
\hline & & \multicolumn{3}{|c|}{ Very important $\quad$ not important } & & \\
\hline 7 & 6 & 5 & 4 & 3 & 2 & 1 \\
\hline \multicolumn{7}{|c|}{0} \\
\hline \multicolumn{7}{|c|}{ 7. Discussing adminis } \\
\hline 7 & 6 & 5 & 4 & 3 & 2 & 1 \\
\hline
\end{tabular}

Figure 2. A comparison between social media and Moodle as forums for teaching practice

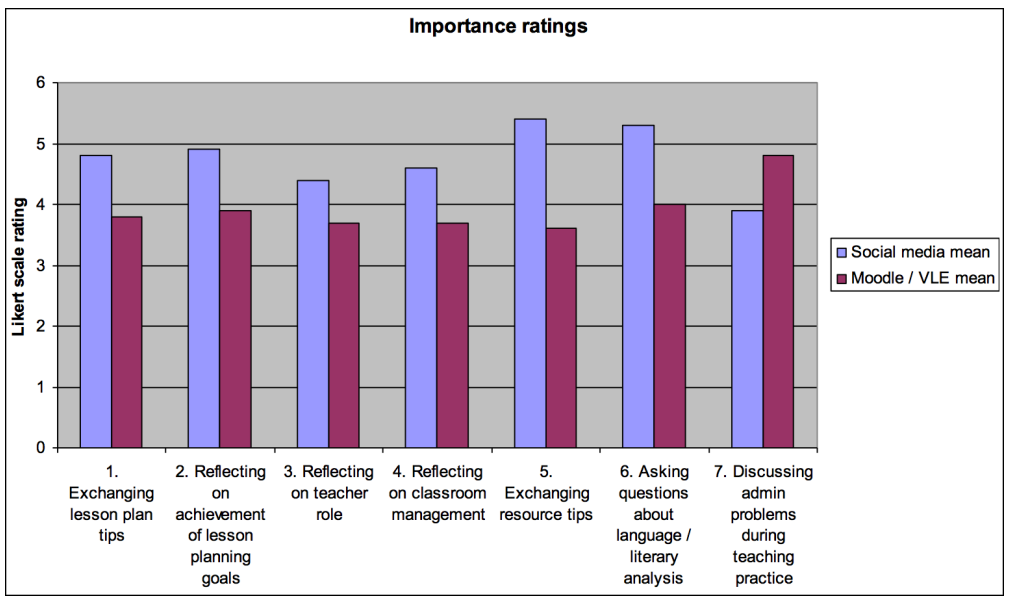


Here there was a clear preference for the use of Moodle when bringing up problems such as how many hours should be taught by the teacher, communication with school supervisors, etc.

\section{Discussion}

A number of factors regarding the preference for social media emerged in the final open question. A significant factor was the presence or absence of the course tutor in the online forum discussions. The closed Facebook group was preferred by a number of students as it permitted the 'ventilation' of both positive and negative aspects of the teaching practice and the course in general without the presence of the tutor. In addition, students mentioned familiarity with the Facebook interface from their private spheres which they saw as being more user-friendly than the VLE. Students also mentioned the ease with which they could submit and reply to postings via mobile devices, while Moodle was frequently seen in terms of more intermittent access via stationary computers.Moodle forums were increasingly seen by the majority of respondents as an institutionally 'owned' platform belonging to their professional development while Facebook seamlessly integrates with their 'private' sphere of personal learning environment. Facebook in this respect was seen as more 'student-centric'. Nevertheless, some critical voices were raised towards the use of social media as a teaching practice discussion medium; several respondents pointed to the tendency for discussion threads to be 'swamped' by irrelevant postings with little connection to the practice period in school.

\section{Conclusions}

There is a clear preference for social media rather than an institutional VLE as a forum for the discussion of teaching practice questions with the exception of purely administrative matters relating to the school internship. This state of affairs is problematic for tutors wishing to provide formative feedback over the duration of the practice period. It is intended that future research arising from this conference paper could seek to evaluate the suitability of virtual learning environments such as Edmodo, which attempt to incorporate the user-friendliness and integration possibilities of social media in a more institutionally-controlled learning environment.

\section{Acknowledgements}

The author would like to thank the Department of Language, Linnaeus University for support in attending the EUROCALL 2015 conference. 


\section{References}

Lave, J., \& Wenger, E. (1991). Situated learning: legitimate peripheral participation. New York: Cambridge University Press.

Prensky, M. (2001). Digital natives, digital immigrants part 1. On the Horizon, 9(5), 1-6. doi:10.1108/10748120110424816

Weller, M. (2006). VLE 2.0 and future directions in learning environments. In R. Philip, A Voerman, \& J. Dalziel (Eds.), Proceedings of the First International LAMS Conference 2006: Designing the Future of Learning, 6-8 December 2006 (pp. 99-106). Sydney: LAMS Foundation. Retrieved from http://lamsfoundation.org/lams2006/papers.htm

Weller, M. (2007a). Virtual learning environments: using, choosing and developing your VLE. Routledge.

Weller, M. (2007b, November 11). The VLE/LMS is dead. The Ed Techie. Retrieved from http:// nogoodreason.typepad.co.uk/no good_reason/2007/11/the-vlelms-is-d.html 


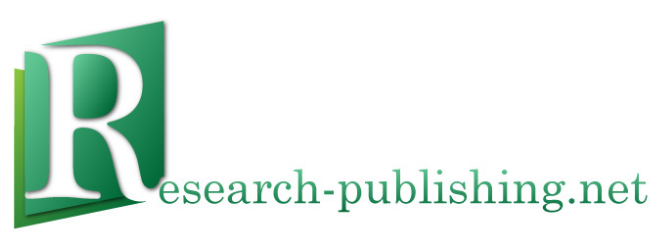

Published by Research-publishing.net, not-for-profit association Dublin, Ireland; info@research-publishing.net

(C) 2015 by Research-publishing.net (collective work)

(C) 2015 by Author (individual work)

Critical CALL - Proceedings of the 2015 EUROCALL Conference, Padova, Italy Edited by Francesca Helm, Linda Bradley, Marta Guarda, and Sylvie Thouësny

Rights: All articles in this collection are published under the Attribution-NonCommercial -NoDerivatives 4.0 International (CC BY-NC-ND 4.0) licence. Under this licence, the contents are freely available online (as PDF files) for anybody to read, download, copy, and redistribute provided that the author(s), editorial team, and publisher are properly cited. Commercial use and derivative works are, however, not permitted.

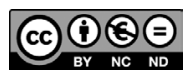

Disclaimer: Research-publishing.net does not take any responsibility for the content of the pages written by the authors of this book. The authors have recognised that the work described was not published before, or that it is not under consideration for publication elsewhere. While the information in this book are believed to be true and accurate on the date of its going to press, neither the editorial team, nor the publisher can accept any legal responsibility for any errors or omissions that may be made. The publisher makes no warranty, expressed or implied, with respect to the material contained herein. While Research-publishing.net is committed to publishing works of integrity, the words are the authors' alone.

Trademark notice: product or corporate names may be trademarks or registered trademarks, and are used only for identification and explanation without intent to infringe.

Copyrighted material: every effort has been made by the editorial team to trace copyright holders and to obtain their permission for the use of copyrighted material in this book. In the event of errors or omissions, please notify the publisher of any corrections that will need to be incorporated in future editions of this book.

Typeset by Research-publishing.net

Fonts used are licensed under a SIL Open Font License

ISBN13: 978-1-908416-28-5 (Paperback - Print on demand, black and white)

Print on demand technology is a high-quality, innovative and ecological printing method; with which the book is never 'out of stock' or 'out of print'.

ISBN13: 978-1-908416-29-2 (Ebook, PDF, colour)

ISBN13: 978-1-908416-30-8 (Ebook, EPUB, colour)

Legal deposit, Ireland: The National Library of Ireland, The Library of Trinity College, The Library of the University of Limerick, The Library of Dublin City University, The Library of NUI Cork, The Library of NUI Maynooth, The Library of University College Dublin, The Library of NUI Galway.

Legal deposit, United Kingdom: The British Library.

British Library Cataloguing-in-Publication Data.

A cataloguing record for this book is available from the British Library.

Legal deposit, France: Bibliothèque Nationale de France - Dépôt légal: décembre 2015. 